\title{
Local security policies and the protection of territory: an analysis of the Italian experience (2007-2009)
}

\author{
Marco Calaresu* and Mauro Tebaldi
}

\begin{abstract}
This paper explores the territorial dimension of local security policies, with reference to the "Security Pacts" signed in Italy between 2007 and 2009. These Security Pacts are an innovative instrument introduced by the central government, aimed at changing the model of security governance at the local level. After describing how Security Pacts have spread, and which institutional actors have participated in them, this study aims at deepening the analysis of their territorial dimension. More specifically, the research question at the basis of this study focuses on the identification of factors that can explain why the pacts feature variations in numbers and types of public administration at different levels, and why they tend to acquire particular spatial configurations rather than others. Three hypotheses are tested based on empirical data (obtained using a Quantitative Narrative Analysis with the aid of Geographic Information Systems and other statistical tools) used to identify which variable may best explain the propensity to use such pacts to solve security-related issues in different areas of the country.
\end{abstract}

Keywords: Local security policy; Security Pacts; Italy; Contractualization of public policies; Quantitative narrative analysis; Geographic information systems; Protection of territory

\section{Background: what "Security Pacts" are, how they spread, and who signs them (2007-2009)}

The security issue is one of the core themes of the public discourse in so-called "full-grown democracies" (Hughes et al. 2002), and it is closely connected to both the trends in types of crimes and the responses from public (governmental, administrative, judicial, penal) authorities on this social issue (Dei Delitti e Delle Pene 2002; Morlino et al. 2013; Pajno 2010). It is also influenced by the perception that people have of both elements (Castels 2003; Simon 2007). In the political market-in particular as far as citizen demand is concerned-an increasingly higher demand for protection of public order has been recorded over the last 15 years, requiring more extensive guarantees on personal safety, better protection against acts of terrorism, and even demands to be able to live a quality life in conditions of "full security" (Boutellier 2004; Bauman 2005, 2008). Security has become a real "obsession" (Curbet 2008) that citizens share, or at least charge to their elected

\footnotetext{
* Correspondence: mcalaresu@uniss.it
}

Department of Political Sciences, Communication Sciences and Information Engineering, University of Sassari, Viale Mancini 5, Sassari 07100, Italy representatives at all levels of government (Garland 1996, 2001; Hughes and Edwards 2002). On the political offer side, at the same time, policy platforms developed to meet that demand and to guarantee a more effective institutional response to the perception of insecurity voiced by the people (Lagrange 1993; Baratta 2001; Pavarini 2006b; Recasens i Brunet 2007; De Micheli and Tebaldi 2013; Moroni and Chiodelli 2014).

Among the different instruments used to inform such policies, we assisted to the spread of contractualization practices (Gaudin 1996, 1999; Lascoumes and Le Galés 2004), to be considered as "one of the most significant processes of political-administrative change" (Bobbio 2000: 112) in contemporary democracies. Through such practices, policies are defined and implemented on different subjects, purposes, stakeholders, territorial scales ${ }^{\mathrm{b}}$ or scopes of action. In practice, they may generally be regarded as explicit agreements on matters of public interest, ${ }^{\mathrm{c}}$ submitted in written form, in which the parties declare publicly to approve a plan or course of action, or mutual commitments; putting their own resources (not necessarily 
financial resources) to a shared purpose, and agreeing on when and how to implement this (Bobbio 2000).

Italy is no exception with regard to the above-mentioned contractualization processes. The topic of urban and local security, although emerging later than in the UK and France (Braccesi 2005: 25; Selmini 2005a: 15-16), was developed in Italy by institutional reforms in the late 1990s (Amendola 2003; Mazzette 2003a; Selmini 2004, 2005b; Braccesi and Selmini 2005; Pavarini 2006a). However, since 2005, the relations of cooperation and collaboration between state institutions, regional and local authorities in the field of security have been institutionalized through the signing of new agreements (Calaresu 2012, 2013), designed to overcome the weaknesses of the previous inter-institutional cooperation model as tested during the so-called "first contractual season" $(1998-2005)^{\mathrm{d}}$. On March $20^{\text {th }}, 2007^{\mathrm{e}}$, a framework agreement on the security of urban areas was signed between the then Minister of Home Affairs Giuliano Amato, ANCI President Leonardo Domenici, and the mayors of the metropolitan cities

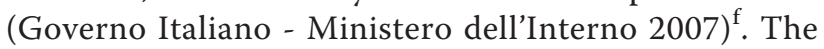
National Pact was designed to initiate-within sixty days-as many agreements as possible within the framework of a relationship of subsidiarity between public bodies and regional and local administrations.

Legislative decree No. 92, formalized on September $13^{\text {th }}, 2008$ with the drafting of another agreement between the National Association of Small Municipalities (ANPCI) and the Ministry of Home Affairs (Law no. 125 of 2008), extends the application of "coordinated plans of territorial control", and the strengthening of logistics and instrumental and financial collaboration between state and local authorities, provided for by the 2007 Finance Act, to small and medium-sized entities; selecting groups of municipalities where the pacts could be implemented (Governo Italiano - Ministero dell'Interno 2008).

The dates reported above mark the days when the "second contractual season" started (2007-2009). The new generation instruments paved the way for a model of security governance different from the previous one, and based on which local administrations seem to be granted the capability to acquire more powers and responsibilities with regard to urban and local security (Martin and Selmini 2000; Calaresu and Padovano 2011). These "Security Pacts" pursue the objective of collaboration between central and peripheral bodies, through the development of an integrated security system; with tasks and responsibilities distributed among different governance levels (Calaresu 2012). In an attempt to start new forms of cooperation between the central government and the local level, the pacts provide a two-fold additional function. On the one hand, they bind prefectures, the peripheral bodies of the central government, to agree to promote certain activities with regional and local authorities, and to share their information. On the other hand, they redistribute responsibilities within the prevention and control functions, allowing local police to cooperate in the fields of prevention and repression with national-level services.

Between 2007 and 2009, 51 Security Pacts were signed in Italy. The only actor that is always present when signing a pact is the prefecture (an agency managed directly by the Ministry of Home Affairs) that signs the agreement with the Municipality, the Province, and the Region, thus generating different institutional configurations (Figure 1).

The municipalities are the main actor involved in the signing of the pacts with the prefectures. Indeed, only on one occasion did the provincial authority sign the agreement without involving the municipality (or more municipalities). The synergy between the municipality and the province is the most widely used $-40 \%$ of the cases-higher than the agreements signed by a single municipality or a group of municipalities with the prefecture (30\%). The full institutional configuration, involving all local authorities (region, province(s) and municipality (s)) is the least common, being perhaps the most difficult to obtain owing to the large number of institutional actors involved in the agreement.

\section{Case description: where have the "Security Pacts" been signed? A preliminary analysis on the geographical areas}

The 51 analysed Security Pacts are not evenly distributed throughout the territory ${ }^{\mathrm{g}}$. As the image below suggests (Figure 2), the pacts are mostly used in the North West (39.22\%) and North East (23.53\%) of Italy. Overall, the North $(62.75 \%)$ had the highest score in comparison with the South (11.76\%), and even more so with respect to the Islands (5.88\%). Even adding the latter share with the percentages obtained from the South and the Centre of the peninsula, the percentage of pacts in the south turns out to be only slightly higher than half $(37.25 \%)$ of the total of the northern regions $(62.75 \%)$.

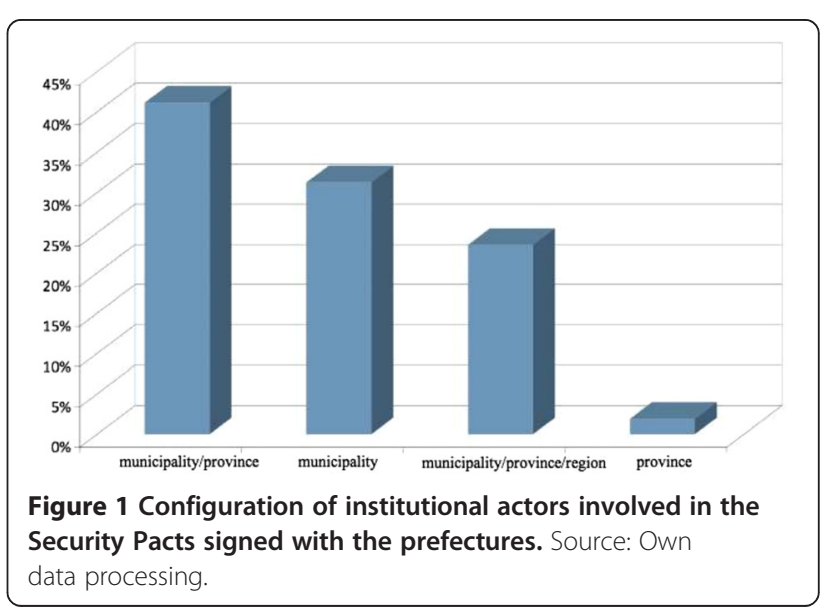




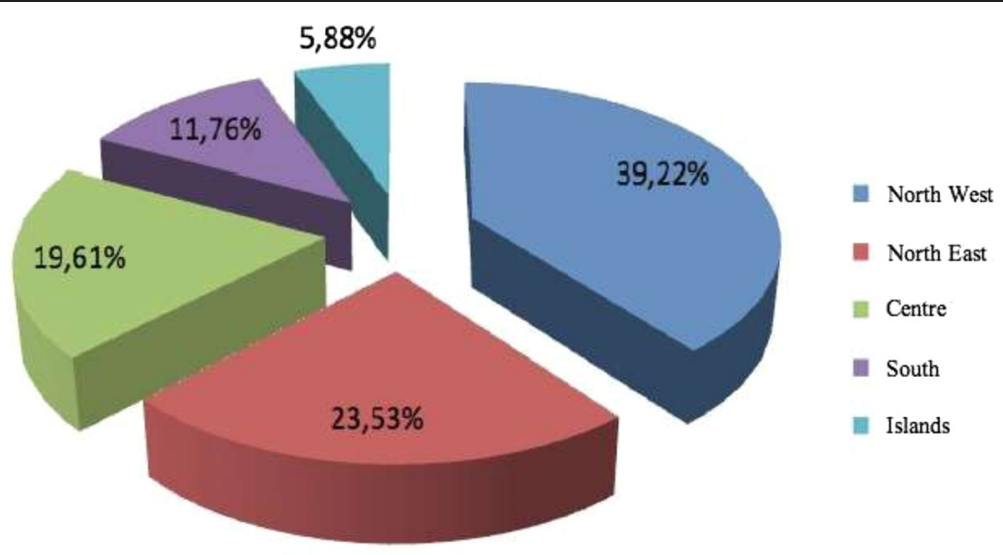

Figure 2 Distribution of Security Pacts by region. Source: Drafted using ISTAT demographic data.

As of December $31^{\text {st }}, 2009,241$ Italian municipalities have been involved in the drafting and implementation of Security Pacts. However, by paying attention to their spatial distribution, on the basis of their belonging to a specific demographic group, data intended simply to show the percentage of the total number of signing municipalities, is information that may be misleading (Figure 3). This is because, with respect to the common conception of security as a typical issue of large conurbations and metropolitan areas, $45 \%$ of the signatories are small and very small-sized Italian municipalities; that is, with a maximum number of 5000 inhabitants.

The data do become more interesting when the additional $25 \%$ is added that includes the share of municipalities ranging between 5001 and 15,000 inhabitants (70\% of the total number of municipalities). From this perspective, larger cities do not seem to be particularly interested in contractualizing security policies. Their

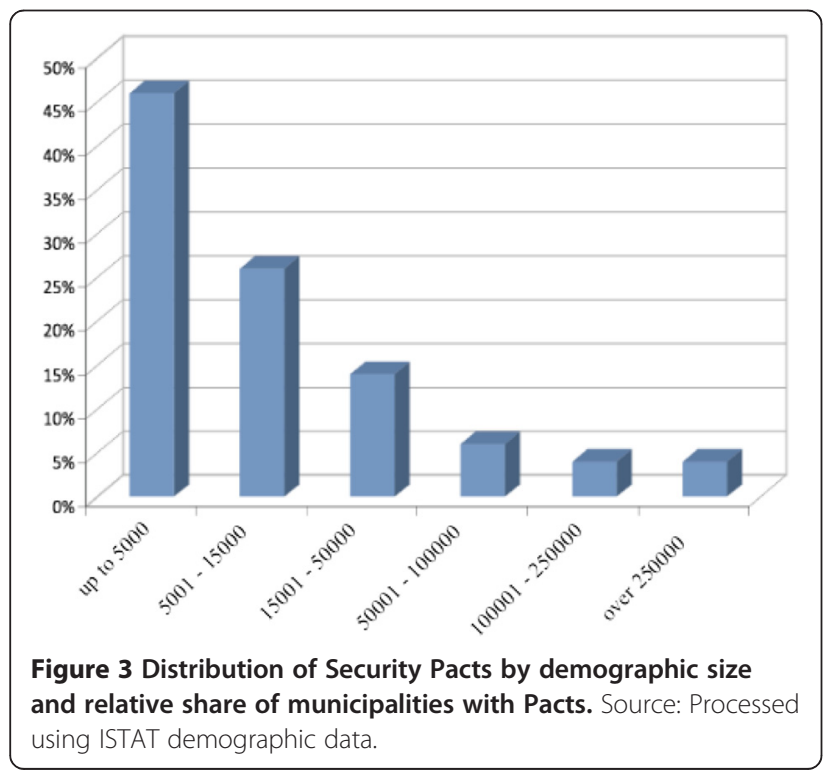

involvement does not exceed 5\% of the total number of signed pacts (Calaresu and Padovano, 2011: 89). However, when the percentage of pacts signed out of the total number of signing municipalities is considered, the result is just the opposite (Figure 4).

Local administrative entities exceeding 250,000 inhabitants contributed $83.3 \%$ of the total pacts (in other words, 10 municipalities out of 12 of the same class), while smallsized towns did not exceed $1.9 \%$ of the total number of Italian municipalities in this category (112 municipalities out of 5739). Table 1 depicts both variables (geographical area and demographic range), providing information on the distribution of the 241 signatory municipalities within the five geographical macro-areas of interest: North West, North East, Centre, South and the Islands.

In the North West, nearly $90 \%$ of the signatory municipalities are reported to be small or very small in size (less than 15,000 inhabitants), but there is a widespread distribution of pacts in the area. While in the South, the

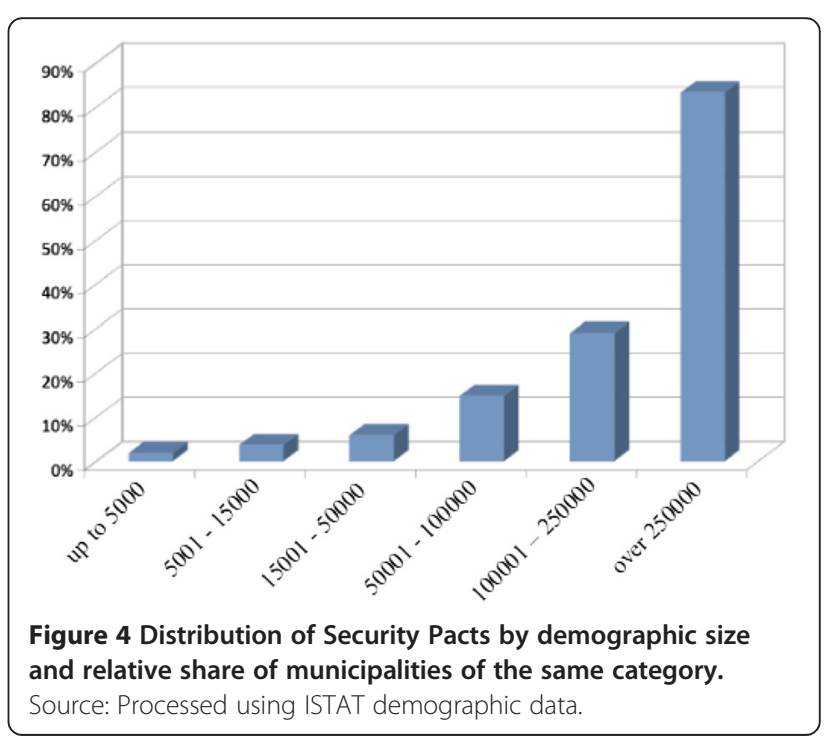


Table 1 Distribution of Security Pacts by geographical area and demographic size of the municipalities with Pacts

\begin{tabular}{llllllll}
\hline Constituency & Up to $\mathbf{5 0 0 0}$ & $\mathbf{5 0 0 1 - 1 5 0 0 0}$ & $\mathbf{1 5 0 0 1 - 5 0 0 0 0}$ & $\mathbf{5 0 0 0 1 - 1 0 0 0 0 0}$ & $\mathbf{1 0 0 0 0 1 - 2 5 0 0 0 0}$ & Over 250000 & Total \\
\hline North West & $67,97 \%$ & $19,53 \%$ & $3,91 \%$ & $5,47 \%$ & $0,78 \%$ & $2,34 \%$ & $100 \%$ \\
North East & $19,51 \%$ & $39,02 \%$ & $24,39 \%$ & $2,44 \%$ & $7,32 \%$ & $7,32 \%$ & $100 \%$ \\
Centre & $21,05 \%$ & $23,68 \%$ & $36,84 \%$ & $5,26 \%$ & $7,89 \%$ & $5,26 \%$ & $100 \%$ \\
South & $0,00 \%$ & $0,00 \%$ & $0,00 \%$ & $33,33 \%$ & $33,33 \%$ & $33,33 \%$ & $100 \%$ \\
Islands & $24,14 \%$ & $41,38 \%$ & $13,79 \%$ & $13,79 \%$ & $3,45 \%$ & $3,45 \%$ & $100 \%$ \\
\hline
\end{tabular}

Source: Processed using ISTAT demographic data.

opposite seems to happen: the municipalities that signed the pacts turned out to be only three in number; all of them being large-sized (between 50,000 and 250,000+).

\section{Discussion and evaluation: the geographical configurations of the "Security Pacts"}

Data and methods: from words to numbers (and maps)

After analysing the background data, the discussion covers empirically relevant aspects connected to the dependent variable being taken into account, that is, the aspects that make it possible to understand the Security Pacts signed in Italy between 2007 and $2009^{\mathrm{h}}$. The goal is to understand the geographical configurations of these pacts. Based on the linguistic and textual characteristics of the afore-mentioned documents ${ }^{\mathrm{i}}$, which may be considered as a "narrative" text, Quantitative Narrative Analysis (QNA) methodology was implemented (Franzosi 2004, 2010). Narrative is a text genre with distinct, perhaps invariant, structural characteristics as follows: 1) chronologically ordered sequences of events, 2) actors doing "things" to the benefit or detriment of other actors, as typically rendered linguistically by the simple structure SVO, Subject-Verb-Object, a structure also known as "story grammar" (an invariant structure of narrative approximately corresponding to the 5 W's of journalism-Who, What, When, Where, Why-with the potential addition of several more elements); and 3) The number of steps in these sequences is limited and invariant within specific narrative types (Franzosi 2004).

QNA is an approach that allows structuring the narrative information contained in documents with the purpose of collecting data into a "story grammar". Security Pacts are indeed characterized by a Subject-Verb-Object structure (SVO). The signing actors (institutional bodies such as the prefect's offices, the municipalities, the regions) mutually commit (or engage other operators, such as the police forces) to achieve objectives (training activities, cooperation, organization...), through specific actions, mostly of a relational nature (coordination, communication, funding, and so on), in a given action space. In a nutshell, QNA, through its "rewrite rules" (Franzosi 2010: 24), allows the encoding of the "events" (Rimmon-Kenan 1983: 2) that are present in the source text, and sets them within an organizational structure consisting of narrative and non-narrative data. Using software specifically designed for this task, PC-ACE', a relational database system was generated (07_SecuPacts_09). More specifically, the relational properties of the database made it possible to convert words into numbers (Franzosi 2004). All the available information contained in the database was then exported (via Structured Query Language) and analysed, for the purpose of this paper ${ }^{\mathrm{k}}$, with the aid of Geographic Information Systems (ArcGIS) ${ }^{1}$ software, and by means of SPSS $^{m}$. ArcGIS software describes the relationships between the stakeholders and related spatial data, on the basis of their common geographical frame of reference. In this study, the maps highlight the spatial distribution of Security Pacts.

The coding of the 51 Security Pacts under study-with a total of 487 pages of documents (and 2671 performed "semantic triplets" $)$-involved 11,652,444 inhabitants; distributed in 241 municipalities. Of these municipalities, 31 are provincial capital cities (11 in the North West, 7 in the North East, 7 in the Centre, 3 in the South and 3 on the Islands) out of a total of 103 , that is $30 \%$ of the total ${ }^{\circ}$. As a first result of the GIS analysis of pacts, Figure 5 shows the association of each pact signed on an area with a specific institutional configuration. However, despite the fact that the municipality/province/region configuration is the least common from a numeric point of view, the map suggests that the dissemination of this combination is connected to strategic and wider areas (such as, the cities of Rome, Genoa, Bari, Bologna, Venice, Florence and Perugia). Figure 6 reports on the distribution of the signatory municipalities within Italy, providing a detailed description of the geographical and institutional boundaries of the local authorities engaged in these pacts. Figures 7 and 8 show the geographical position of the 28 provincial governments and seven regional entities that undersigned the pacts.

\section{Why there? Three hypotheses on security localization}

This section focuses on the identification of the reasons why local administrations in different areas of the country tend to use pacts as instruments to solve security-related issues. In particular, it focuses on the analysis of the 


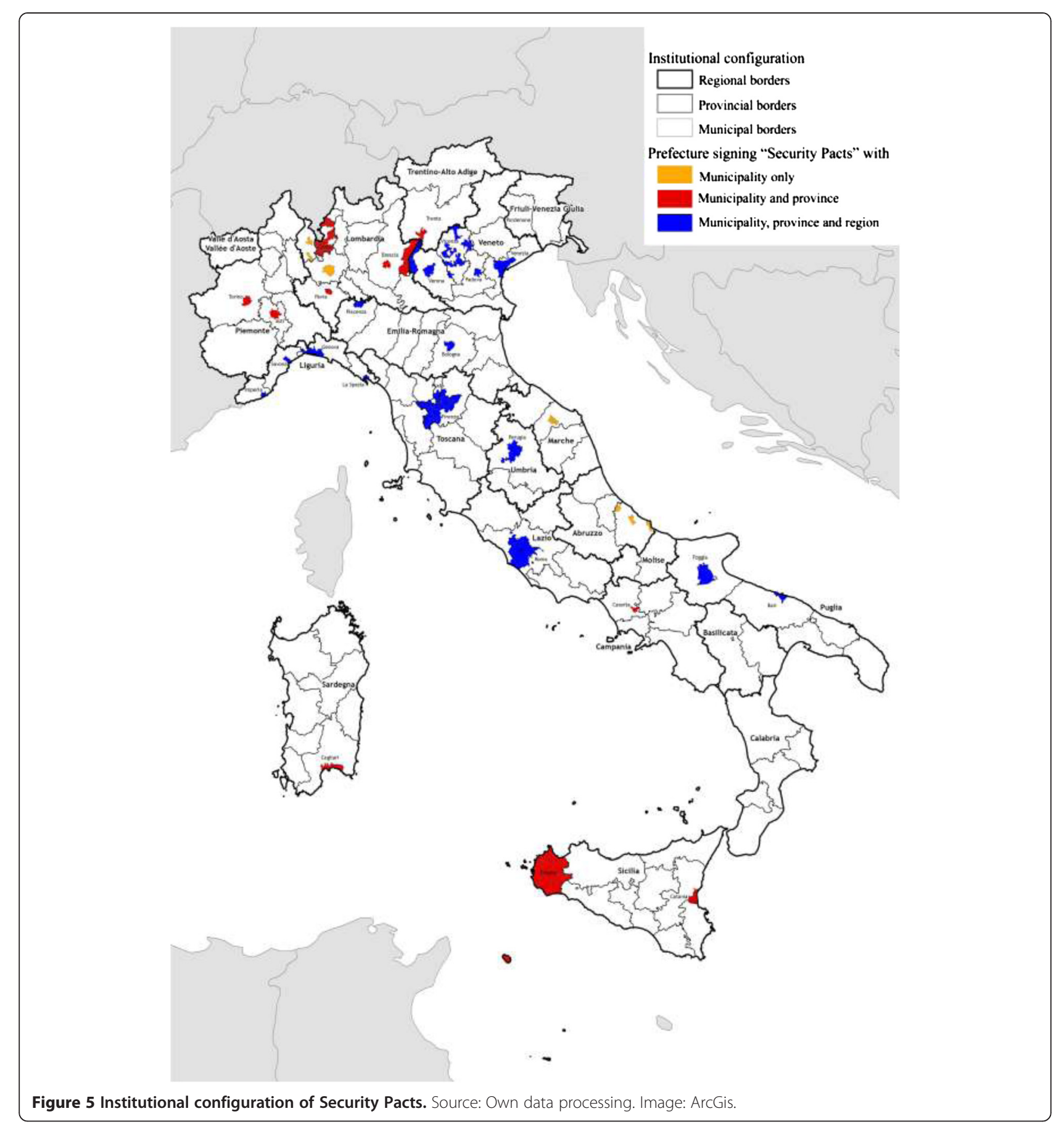

factors that may persuade administrations to create specific geographical configurations; namely to adjust this security tool based on specific spatial and administrative boundaries, and with specific goals. Three hypotheses were constructed for empirical testing:

Hypothesis 1: The specific territorial configurations of Security Pacts depend on the political colour of the majority party or majority coalition running local institutions. A pact is the result of specific policy choices connected to the will of the political parties involved, and tends to occur whenever the institutions that initiate it have the same political affiliation.

Hypothesis 2: Regardless of their political colour, the spatial configuration of the Security Pacts depends on the size and demographic density of urban areas. The most densely populated regions tend to be those with the highest concentration of criminal acts, and therefore, they require institutional arrangements to combat the 


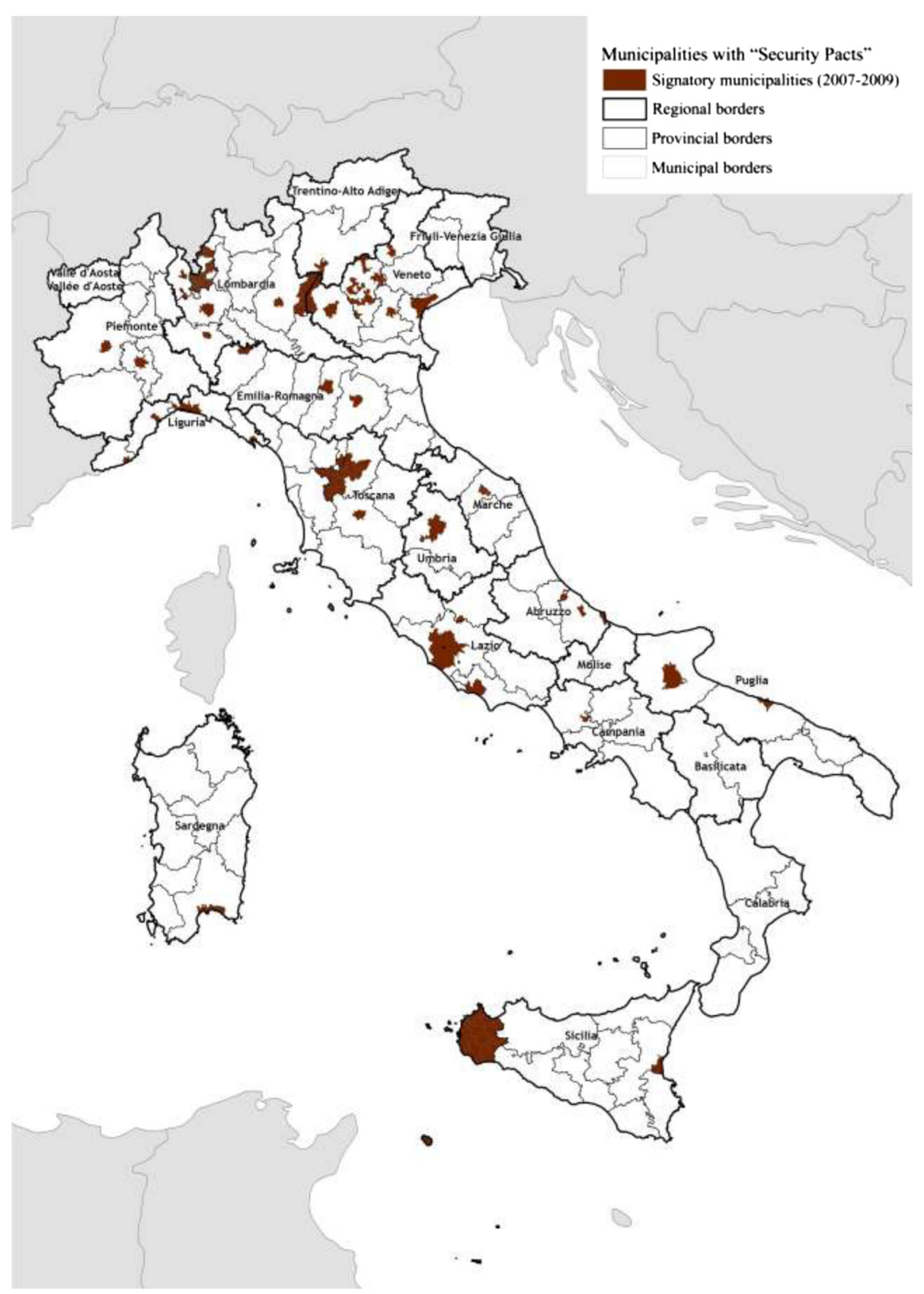

Figure 6 Municipalities with Security Pacts. Source: Own data processing. Image: ArcGis.

social disadvantage that crime generates. In this case, the pacts acquire specific spatial configurations, since such configurations are the most likely institutional response to the geo-localization of crime.

Hypothesis 3: Regardless of their political colour, range, demographic density and the resulting geo-localization of crime, Security Pacts are connected to specific territories and their social and economic features, and are characterized by high levels of wellbeing and the quality of life of their inhabitants.
Do politics matter? "Security Pacts" and the connotation of the political majority

This section aims at testing the first hypothesis: that is, the one identifying the political colour of governments at different levels as the independent variable determining the localization of the use of Security Pacts. First, we should ask ourselves whether pacts (as a whole, regardless of the number of local and regional signing parts) had a specific political connotation, whether they were implemented mostly by the right-centre or left-centre 


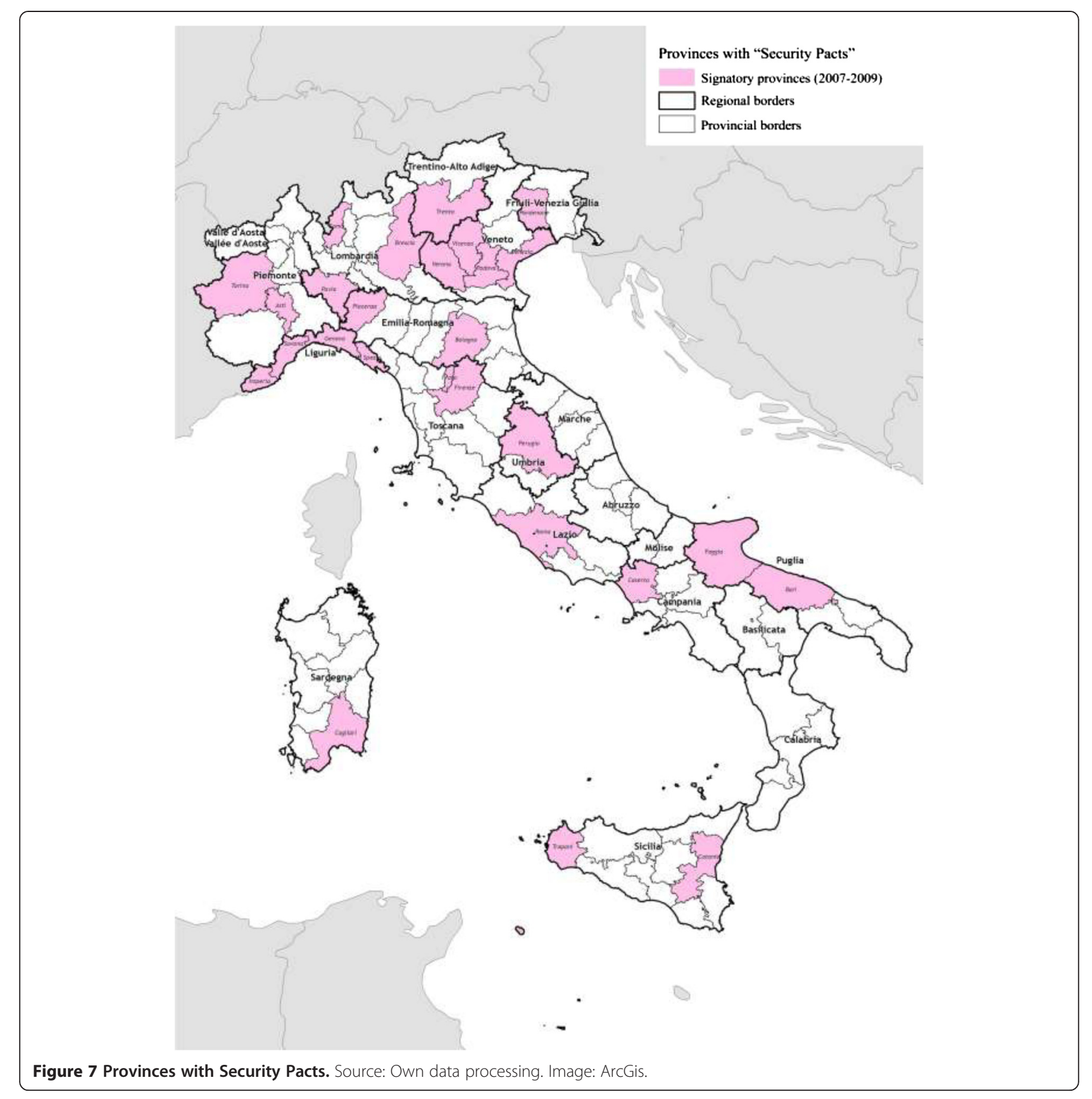

local administrations. With this aim in mind, and using data extracted from the Registry of Local and Regional Directors - Department of Internal and Territorial Affairs of the Ministry of Home Affairs, each administration involved was labelled as right-centre, left-centre, and other ${ }^{\mathrm{P}}$ based on the affiliation of the mayor, and/or the President of the region or the province, who signed the pact at the time of their election ${ }^{\mathrm{q}}$. By summing up the different positions, including the political connotation of the national government at the time of signing, each pact was labelled as homogeneous or mixed. Homogeneous meaning that within the pact each administration involved belonged to the same political area, resulting in the presence of a prevailing orientation (right-centre or left-centre). Conversely, mixed refers to the absence of such political orientation. Inhomogeneous is reported when at least one of the contracting actors belonged to a political area different from the rest of the signatories. Figure 9 shows the results of the above-mentioned process: interestingly, the pacts do not show any particular political connotation. The 


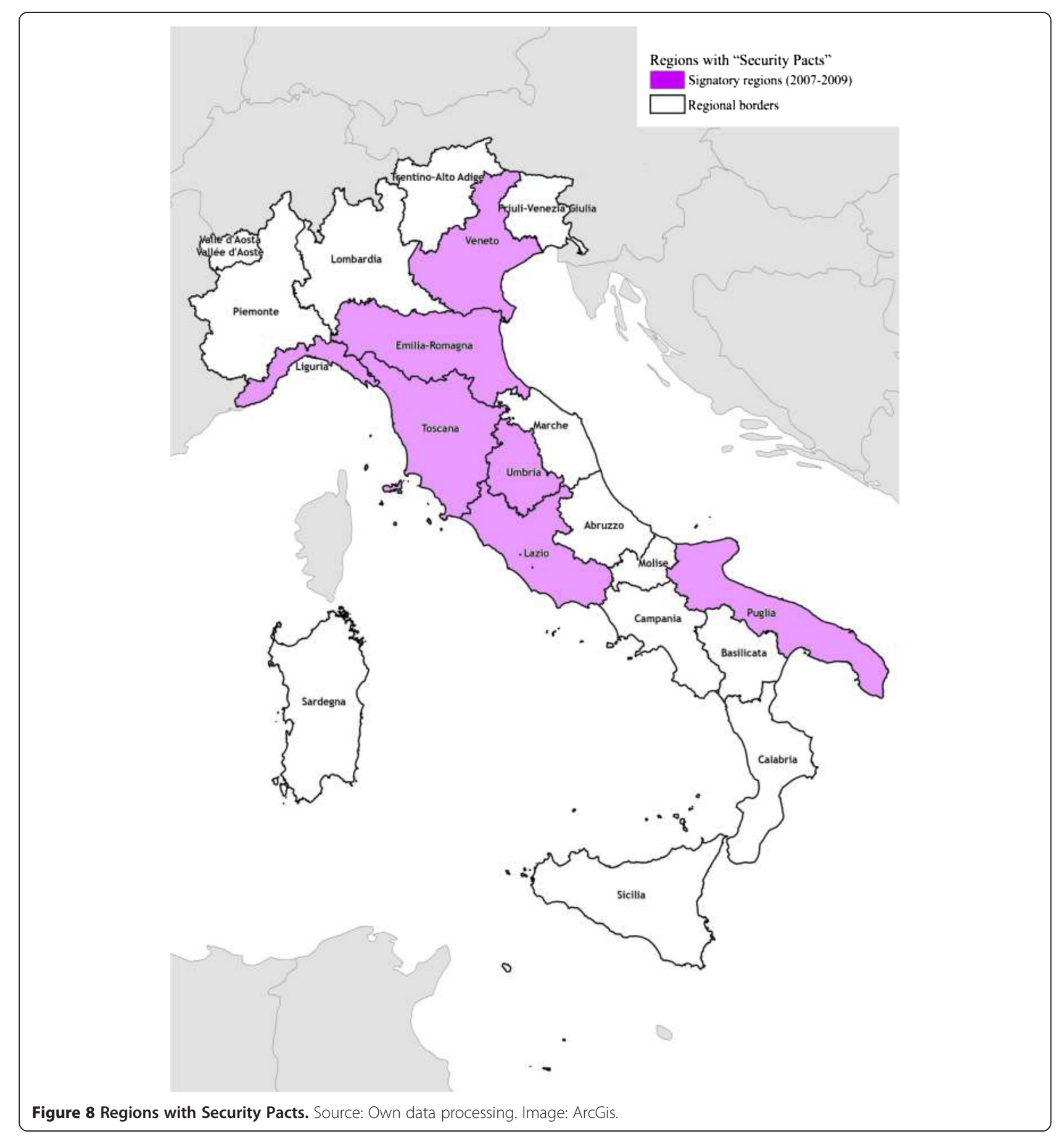

administrations implementing this instrument do not seem to belong to a specific political area, while a slightly higher number (39\%) of mixed pacts is reported.

Keeping the single pact as the reference unit of measure, it is possible to identify connections between the political colour of the pacts and their national geographical distribution by macro-area. Most interestingly, in the North West of the country, $60 \%$ of the pacts were signed by right-centre political majorities, including the national government in charge at the time of the agreement. This is almost certainly due to the greater spread of right-centre administrations in this area, with respect to the national total, as well as the greater presence of small and very small-sized municipalities in the region (with respect to the national total). However, since consolidated data are not available, it is not possible to confirm this relationship. If the unit of reference changes, moving from a single pact to the 241 municipalities involved in the signing 


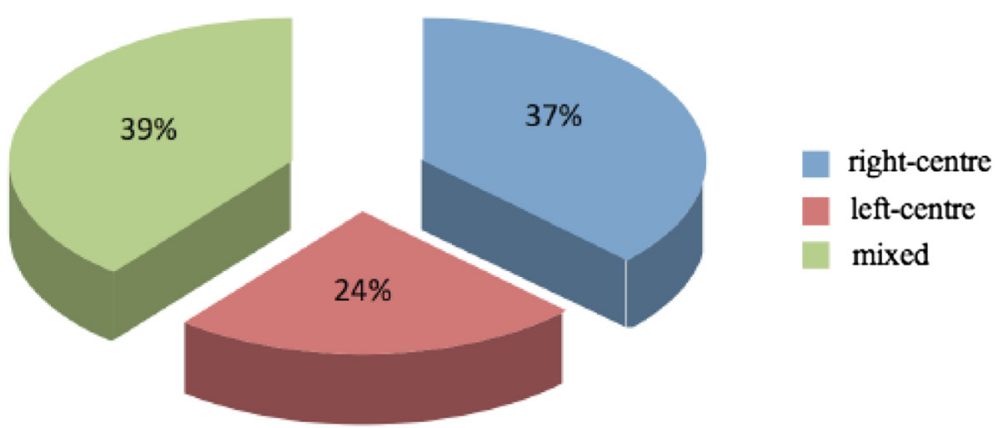

Figure 9 Political connotation of Security Pacts. Out of a total number of 51 documents, based on the signatory administrations and the national government. Source: Own processing of the data extracted from the Register of Local and Regional Directors - Department of Internal and Territorial Affairs of the Ministry of Home Affairs.

of the 51 documents analysed, the result is the same. A total of $57 \%$ of the signatory municipalities belong to the mixed group, while the right-centre and left-centre municipalities share the remaining pie (Figure 10). This is a result of the fact that $45 \%$ of the municipalities involved in Security Pacts are small and very small-sized municipalities (see Figures 3 and 4), where the so-called civic lists or independent groups are widespread, as well as the personal parties, which may not be labelled as either left-wing or right-wing.

This picture changes when the institutional configuration associated with the political connotation of the pacts is taken into account, based on the mixed-homogeneous political connotation process described above (Table 2). The data show that, taking into account the full institutional configuration-an agreement is reached between the local authorities (region, provinces and municipalities) together with the prefectures- $75 \%$ of the pacts were finalized by left-centre administrations, with the presence of a national government of the same political affiliation. Conversely, right-centre administrations did not manage to obtain the same results ( $0 \%)$. Keeping in mind that the full configuration was the least common (Table 2), being perhaps the most difficult to obtain due to the large number of institutional actors involved in the agreement, it can be seen that the contracting left-centre stakeholders were the most effective in reaching an agreement on a shared medium to long-term project, or at least they were more likely to reach such agreement than those belonging to the right-centre area, including a large number of institutional actors. However, right-centre administrations relied on the collaboration between the municipality and the province (52.3\%), excluding the region.

\section{Size of population, demographic density and "Security Pacts". Which kind of relationship?}

This section is dedicated to the empirical test of the second hypothesis. This hypothesis emphasizes the correlation between demographic density, the probability of criminal behaviour, and the need for the government to implement Security Pacts to combat the social disadvantage that crime generates.

The analysis focuses on the pacts signed in the cities of Milan, Varese and the Como Lake area. The use of such instruments, as Figure 11 shows, is widespread, since it affects a large number of administrations (89 municipalities), with different institutional configurations (municipality and municipalities/provinces). The map shows the institutional boundaries of the pacts, starting with the "Patto per Milano sicura" that involve the municipality and the Prefecture only. Milan appears as a compact city, the capital of a densely populated province in the centre of a metropolitan

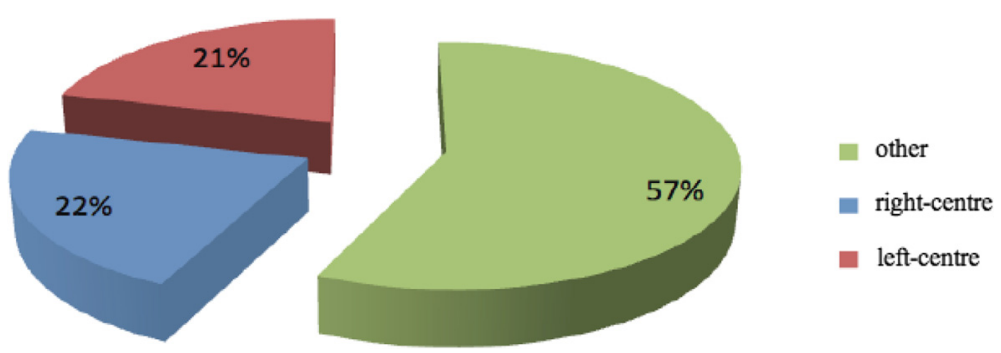

Figure 10 Connotation of the political majority of the municipality and signing of the Security Pacts. Out of a total number of 241 signatory municipalities, regardless of the affiliation of the national government. Source: Own processing of the data extracted from the Register of Local and Regional Directors - Department of Internal and Territorial Affairs of the Ministry of Home Affairs. 
Table 2 Institutional configuration and political connotation of the Security Pacts

\begin{tabular}{|c|c|c|c|c|c|c|c|c|}
\hline Institutional configuration & Right-centre & Left-centre & Mixed & tot. & $\%$ rc & $\%$ Ic & $\% \mathrm{~m}$. & tot. \\
\hline Municipality & 6 & 3 & 8 & 17 & $35,2 \%$ & $17,6 \%$ & $47,0 \%$ & $100 \%$ \\
\hline Municipality/province & 11 & 1 & 9 & 21 & $52,3 \%$ & $4,7 \%$ & $42,8 \%$ & $100 \%$ \\
\hline Municipality/province/region & 0 & 9 & 3 & 12 & $0,0 \%$ & $75,0 \%$ & $25,0 \%$ & $100 \%$ \\
\hline Province & 1 & 0 & 0 & 1 & - & - & - & $100 \%$ \\
\hline Total & & & & 51 & & & & \\
\hline
\end{tabular}

Taking into account the national government. Source: Data extracted from the Register of Local and Regional Directors - Department of Internal and Territorial Affairs of the Ministry of Home Affairs.

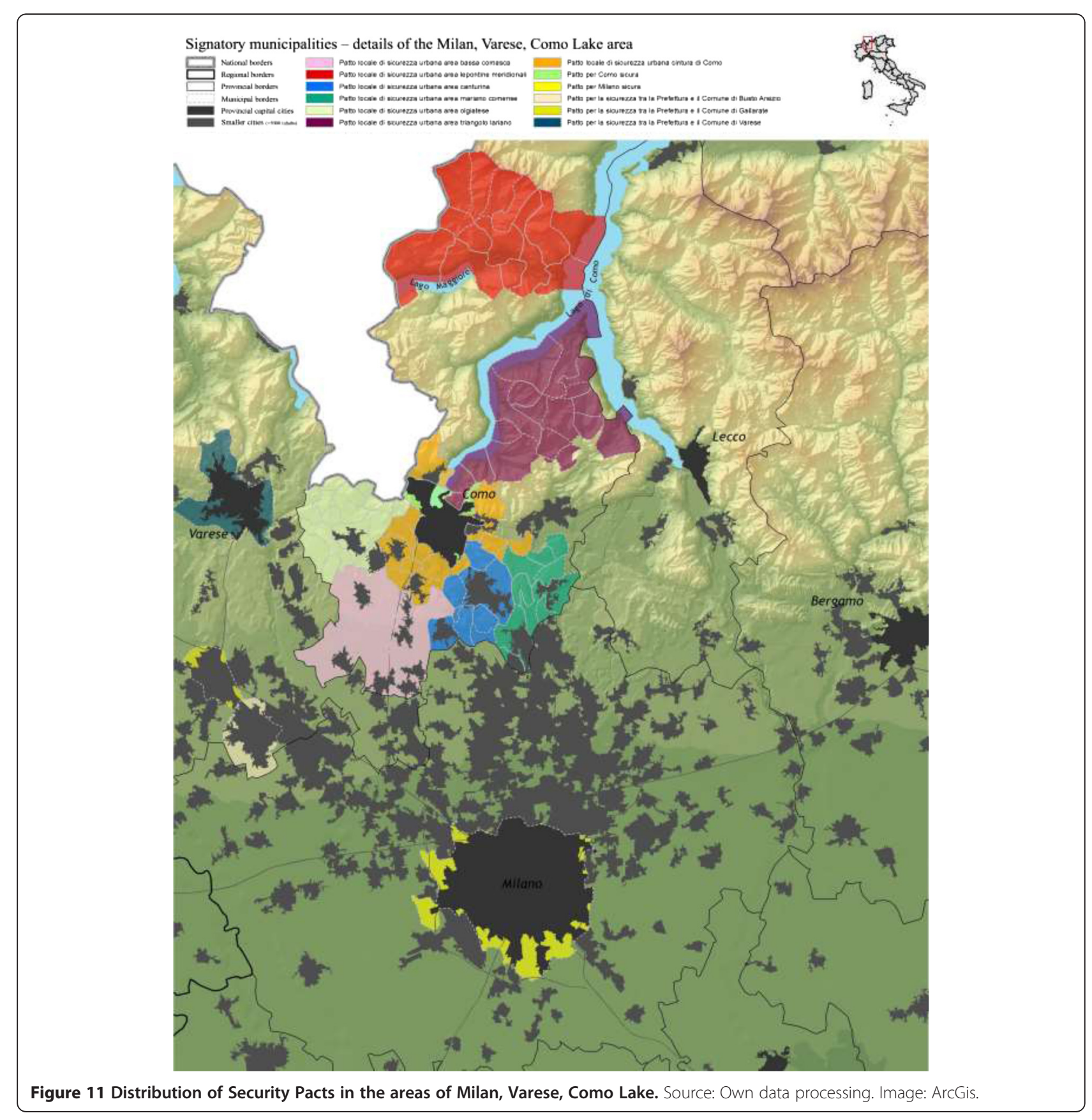


area (see Allulli 2010; Allulli and Tortorella 2014), that stretches to the North and North East through diffused urban settlement, reaching the towns of Busto Arsizio and Gallarate. These cities also signed a security pact, in collaboration with the Prefecture of Varese. A little further to the North, Varese (the capital city of the province) signed its own pact in agreement with the Prefecture. Turning to the West, near the Swiss border, the city of Como reached an agreement with its Province and the Prefecture, as part of the "Patto per Como sicura" initiative. Around the provincial capital city, is a sparsely populated area stretches (i.e. an area with a low ratio between the number of inhabitants and the surface area) where the smaller towns (in some cases with more than 5000 inhabitants), teamed up to agree on a number of pacts within the same province. For instance, the municipalities located within the "Como belt" mark a safe zone that surrounds the city of Como as a whole. To the south, three separate covenants ("Patto locale di sicurezza urbana per l'area Mariano Comense", "Patto locale di sicurezza urbana per l'area Canturina", "Patto locale di sicurezza urbana per l'area Bassa Comasca") involving 35 municipalities ${ }^{\mathrm{s}}$ mark an additional belt around the city border. The "Patto locale di sicurezza urbana per l'area Olgiatese" completes the belt around the city of Como, involving a vast area to the West of the city, where no municipality exceeds 5000 inhabitants ${ }^{\mathrm{t}}$. To the North, also the triangle underneath the two stretches of the Como Lake area is included in a pact ("Patto locale di sicurezza urbana dell'area Triangolo Lariano"), as the result of the institutional joint initiative of the Prefecture, the Province of Como, and a multitude of small-sized municipalities not exceeding 5000 inhabitants $\mathrm{u}$. This area is characterized by being a part of an area of privileged conditions in terms of wealth and tourism. Along the national border, near the Maggiore Lake, another pact area was developed with characteristics similar to the previous one ("Patto locale di sicurezza urbana per l'area Lepontine Meridionali"). It is also an area with deeply rooted historical and environmental values, characterized by the presence of non-urbanized municipalities ${ }^{\mathrm{v}}$ (Chiodini and La Nave 2010: 32-33).

What happened in the Milan-Como-Como Lake territory seems to have had many similarities with that in the Garda area (Figure 12), as well as in the Florence area (Figure 13). As Figure 12 shows, the use of pacts in the Garda area is widespread across a great number of local administrations (28 municipalities) with different institutional configurations (municipality and municipalities/ provinces). The city of Verona and the city of Brescia, on the boundaries of the map (Figure 12), confirm the trend of medium-large cities to agree upon security arrangements directly with the Prefecture, while in the Garda Lake area, small-sized administrative bodies (in very lowly populated areas or non-urbanized areas) join and protect a region characterized by a remarkable quality of natural landscapes and historical resources, as well as by high concentrations of "wealthy" economies (Chiodini and La Nave 2010: 32-33). The "Patto per la sicurezza dell'area del Lago di Garda" includes an association of municipalities mostly with less than 5000 inhabitants, within an area that has a tourist vocation (Chiodini and La Nave 2010: 104), and high levels of social wellbeing and wealth ${ }^{\mathrm{w}}$. Figure 12 shows that the "Patto per la sicurezza dell'area del Lago di Garda" signed by the Prefectures of Verona and Brescia (as well as the Port Authority of Venice) marks a new cross-provincial institutional border, thanks to the participation of the Provinces of Brescia, Verona and Trento, going beyond the traditional administrative partition of the area.

The same applies to the area of Florence (Figure 13), starting with the "Patto per la sicurezza dei comuni del Circondario dell'Empolese Valdelsa”. Signed by 11 local administrations with the Prefecture of Florence, it covers an area characterized by low levels of urbanization ${ }^{\mathrm{x}}$, in a territory once again characterized by a very high environmental value, as well as by high levels of social wellbeing and wealth (Chiodini and La Nave 2010: 104). Compared with the cases described above, however, two peculiar behaviours of local administrations in this area are to be noted: the city of Prato - "Patto per Prato sicura", and the city of Florence - "Patto per Firenze sicura", which are medium to large-sized cities as well as provincial capitals, found it necessary to sign pacts in addition to the ones with the Prefecture, trying in this way to enlarge the use of the instrument and the level of coordination with other local authorities. As far as Prato is concerned, the pact also involved the Province of Prato and the Tuscany Regional Authority. However, in Florence, in addition to the Province and the Region, several small towns were involved ${ }^{y}$ in a peripheral area characterized by a high environmental profile (Chiodini and La Nave 2010: 38).

Based on the data described in Figures 11, 12 and 13, it is possible to draw a picture of the contractual behaviour adopted by the administrations involved in the subscription of pacts (2007-2009): 1) as expected, a widespread use of the pact instrument may be seen in provincial capital cities, as well as in cities having between 50,000 and 250,000 inhabitants, which serve as local poles of attraction (Milan, Varese, Gallarate, Busto Arsizio, Como, Brescia, Verona). This particular administrative level does not seem to feel the need (with the exception of Florence and Prato) for an agreement with nearby municipalities, nor with the provincial or regional authorities, possibly believing that a single pact undersigned with the Prefecture would be enough. The high demographic density as well as the social and economic characteristics of this territory suggest that these conurbations may suffer from security issues 


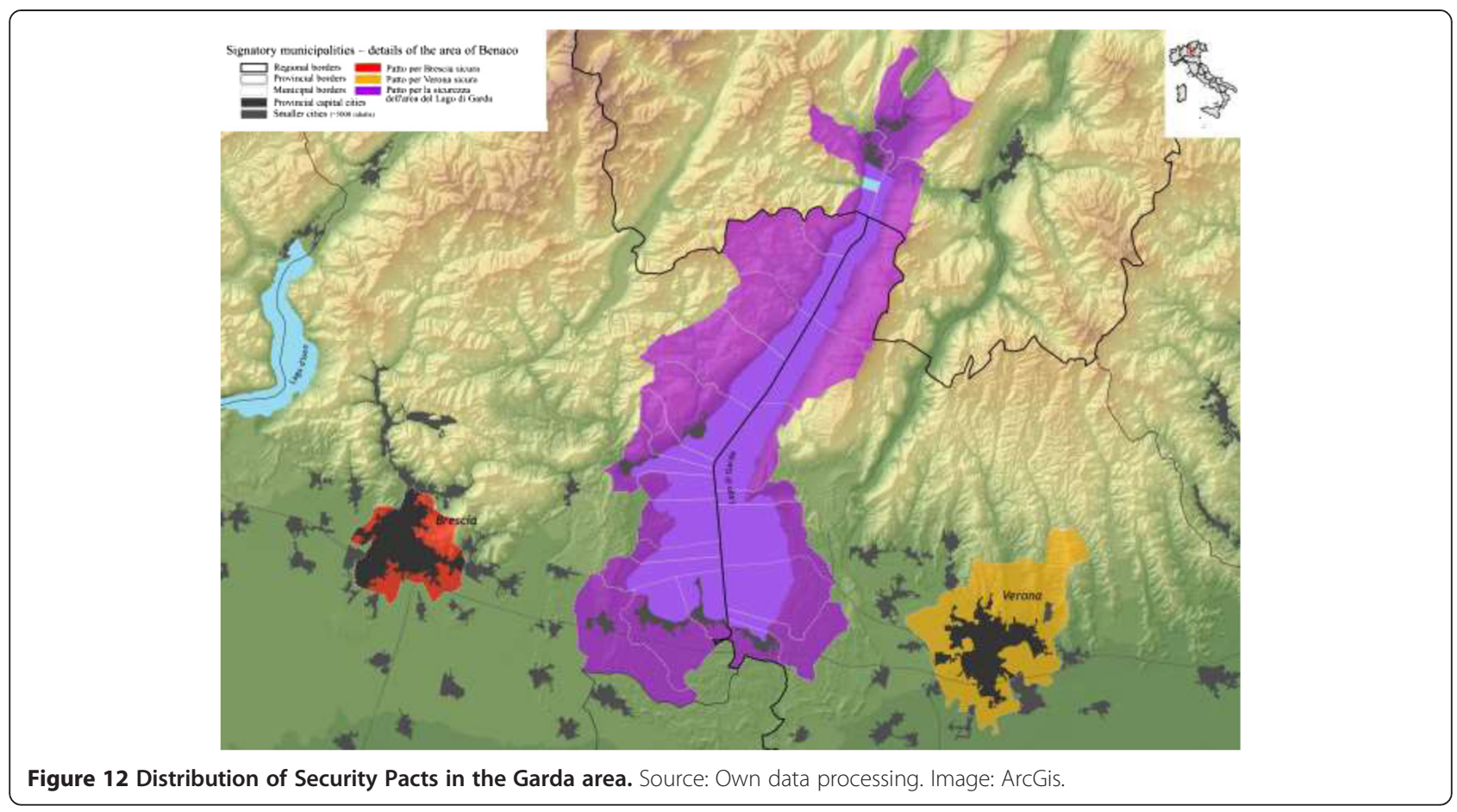

related to high predatory crime rates or migratory waves typical of hot suburbs, or neighbourhoods characterized by urban decay and/or social issues; 2 ) frequent use of this instrument is observed among associated small and very small-sized administrations, located in what Giovanni Maciocco labels as "empty landscapes", as opposed to those that are "more densely developed" (Maciocco 2007: 30). This solution was explicitly encouraged by Article 17 of Law 128/2001, supplemented by Article 7 of the Law of May 23rd, 2008, No. 92 (as amended July 24th, 2008, No. 125), which provided for smaller municipalities or an association thereof to manage in associated form any

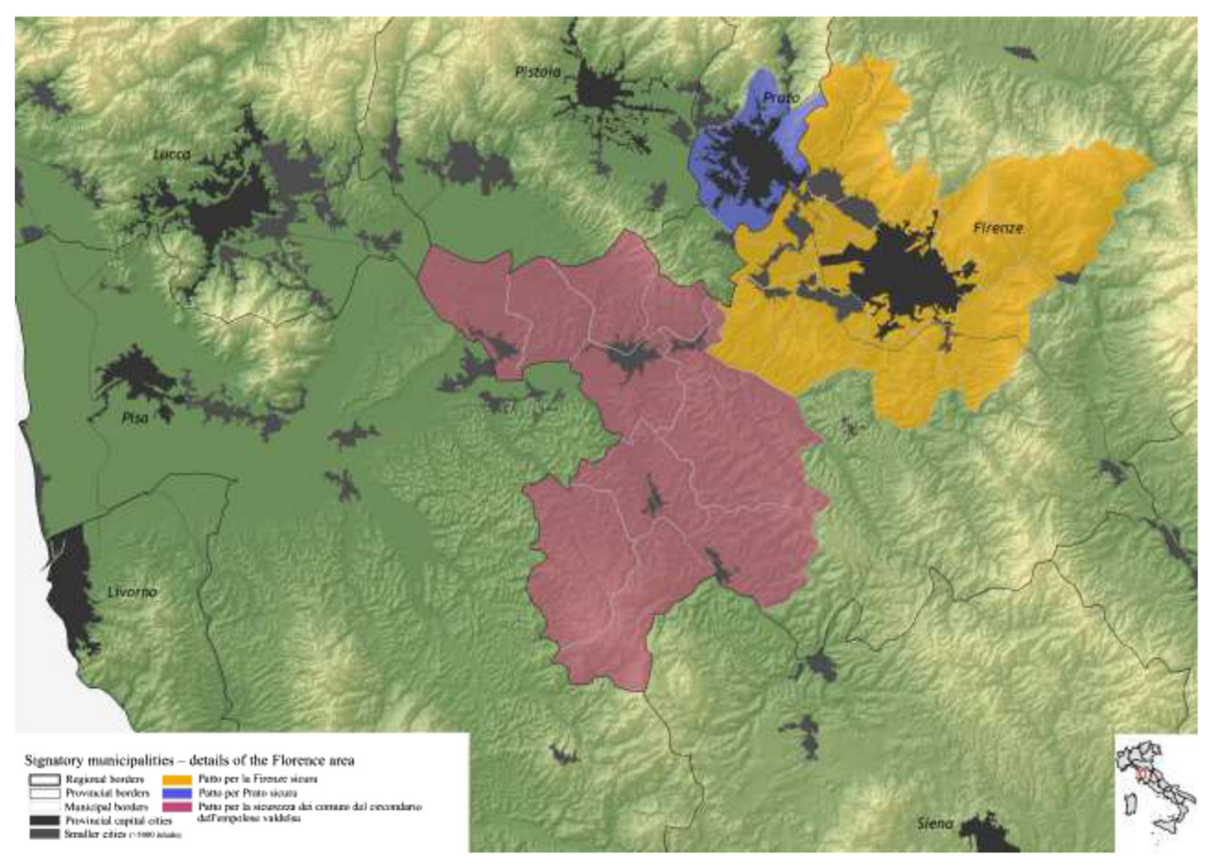

Figure 13 Distribution of Security Pacts in the Florence area. Source: Own data processing. Image: ArcGis. 
security-related issues. These enjoyed the technical support of the National ANCI Association -to ensure "an adequate exercise of municipal powers in matters connected to law enforcement, in particular to facilitate the enhancement of the intervention capacity of local police in ordinary activities and to facilitate the State Police Corps, the Carabinieri Legion, and the Guardia di Finanza in their involvement in crime prevention activities, and control of the territory"z (Antonelli 2010: 93-94).

The outcome of this recommendation was not obvious at all, for three reasons. First, because it was not clear how each municipality would feel about it. Second, because the legislation granted the parties involved the freedom to choose the most appropriate partners to achieve securityrelated objectives. Third, because although the association aimed at "managing security-related issues", and provided for generic objectives to be achieved (such as, strengthening the capacity of local police to deal with ordinary crime), it was clear that the factors leading the mayors of small towns such as Castelfiorentino, Fiesole, Desenzano, Garda, Cusino (just to name a few) to sign a security pact, could not be the same as those faced by the mayors of intensely urbanized areas ${ }^{\text {aa }}$ such as Milan, Brescia and Varese. It is therefore necessary to analyse the contractual behaviours pursued by the contracting authorities to understand how the individual municipalities have adjusted the legislative framework to these aspects; and in particular, the possible incentives (positive or negative) which may have brought smaller municipalities to sign an agreement on security-related matters.

Figures 11, 12 and 13 show how administrations in areas with a low or very low demographic density, and geographically far from the regional capital city (Como Lake area, the areas of Florence, Empoli, Garda Lake) decided to adopt a security pact, joining together with the Province and the Prefecture (more rarely with the regional authority and/or with the capital city of reference, except in the case of Florence and Prato). As already noted, the guiding thread connecting all municipalities is their high historical value, and the high levels of social wellbeing and wealth of its population. In this sense, Maciocco's words (Maciocco 2007: 30) seem to be confirmed by the empirical data: "[...] alternative reference points from the stereotypes of the compact city, refuting the widespread assumption that the city is the 'only thing of interest' [...]". These data highlight the fact that local governments put into practice what was suggested by those sociologists who have studied the connection between urbanism, urban planning and the institutions ${ }^{\mathrm{ab}}$. They prove to have enough institutional intelligence to draw new borders, identifying a security area based on specific social and economic features, rather than sticking to the traditional Italian administrative partition (Municipality,
Province and Region) ${ }^{\mathrm{ac}}$. In some cases, the new institutional border acquires a cross-provincial (in addition to a cross-municipal) profile. That is, they are able to go beyond the traditional provincial borders (Brescia, Verona and Trento; Figure 12).

\section{The social and economic features of urban areas and the use of "Security Pacts"}

The third case aims at understanding whether social and economic wellbeing is to be considered a significant factor in explaining the propensity to use Security Pacts in specific areas, and in specific inter-institutional configurations. The three highlights (Milan-Como-Como Lake area, the area of Benaco, the Florence area) suggest that there may be some kind of correlation between the Security Pacts specifically signed by municipal authorities, and the levels of social wellbeing and wealth of an area. Other authors have already explored this type of assumption. Battistelli and Lucianetti (2010), for instance, argue that such high living standards, accompanied by high levels of economic development, lead to the development of post-materialistic needs (Inglehart 1996); which in turn would result in "forms of participation, aesthetics and selffulfilment"ad (Battistelli and Lucianetti 2010: 46). This has the effect of boosting, within the political security market, both the demand side and the supply side of the security good. Battistelli and Lucianetti regard Italy as a country "split in half" ${ }^{\text {ae }}$ : the North representing the emergence of post-materialist needs, such as urban security; while the South (or rather, the Mezzogiorno) "oppressed by structural setback" ${ }^{\text {"af }}$, cannot meet the citizens' need for employment and personal safety.

To formalize this hypothesis, we might say that municipalities with a higher level of social wellbeing and wealth (in this case regardless of their population), are more likely to use Security Pacts (thus demonstrating a higher securityrelated interest); whereas it is expected that the municipalities with a low level of social wellbeing and wealth have a minor interest towards the same instrument. To test the validity of this hypothesis, available data (referred to as pacts signed by municipalities during the years 20072009) were cross-checked with data released by Eurostat ${ }^{\mathrm{ag}}$ for the year 2007. These data were relevant to the per capita gross domestic product $(\mathrm{GDP})^{\text {ah }}$, measured in terms of Purchasing Power Standards (PPS) ${ }^{\text {ai }}$ by macrogeographical area aj, ak.

As a result, our initial hypothesis is confirmed in four out of five cases (Figure 14). The empirical evidence shows that a high level of income (GDP per capita, PPS) is connected to the highest percentages of municipalities signing a security pact during the period under consideration. The North West, where the highest levels of income are reported, also has the highest percentage of registered pacts. The North East and Central areas are 


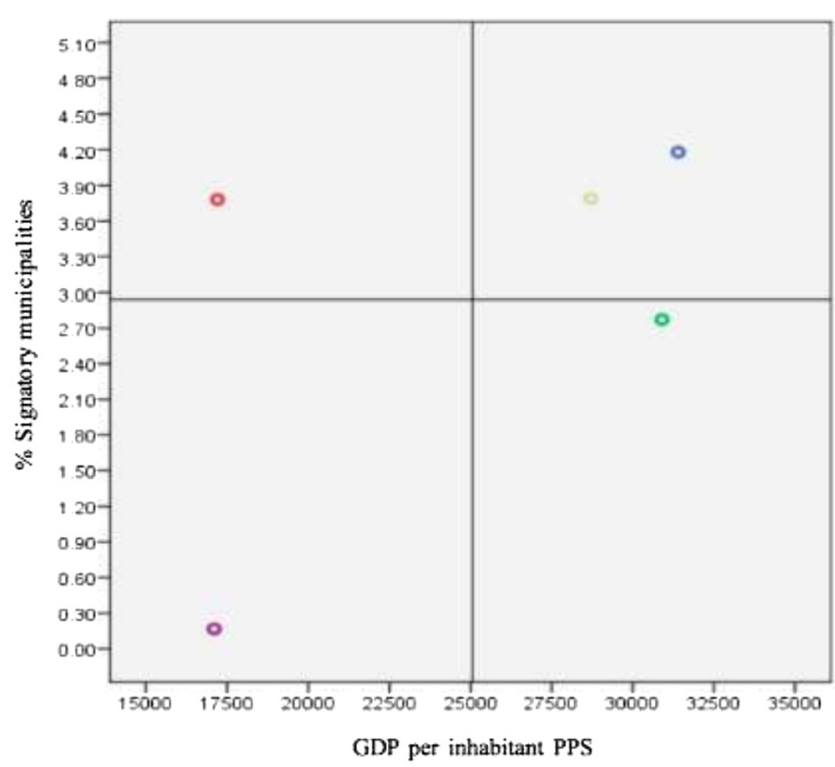

\section{Area}

North West

North East

Centre

South

Islands

Figure 14 Percentage of municipalities with Security Pacts and GDP per capita PPS by geographical area. Source: Processing of Eurostat "Regional GDP per Inhabitant 2007 in the EU27". Released 18 February 2010 al.Demographic data source: ISTAT. Image: SPSS.

reported below. The South has the lowest income levels and the lowest number of pacts signed. The exception is the Islands (Sicily and Sardinia), which has values similar to Central Italy as for the percentage of pacts implemented, but rather lower with regard to gross wealth per capita (GDP-PPS).

The picture is the same if the available data related to the pacts signed by the municipalities (during the same period of time) are coupled with another social and economic welfare indicator: the quality of life in Italian municipalities, published on an annual basis by Italia Oggi $(2007)^{\mathrm{am}, \text { an }}$. This value is measured based on seven different indicators, to capture different aspects of the social and economic welfare connected to GDP level: 1 ) business and labour; 2) the environment; 3) crime; 4) poverty; 5) services; 6) leisure; 7) general. The 7th was used for our test.

The results show that Southern Italy has the lowest level of social and economic welfare (quality of life) and the lowest relative share of signatory municipalities. Even using the general index of quality of life as a measure of wellbeing,

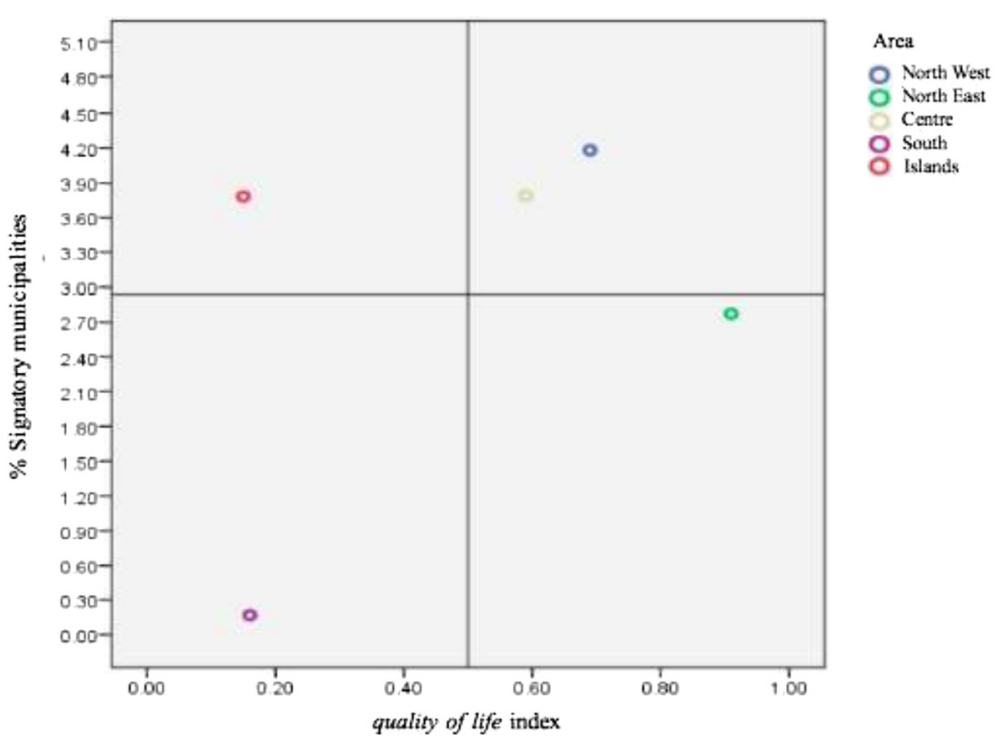

Figure 15 Percentage of municipalities with Security Pacts and quality of life index by area. Source: Own processing of data extracted from Italia Oggi (2007). Demographic data source: ISTAT. Image: SPSS. 
the North West, the North East and Central Italy are at the top of the Italian rankings, with a higher percentage of Security Pacts being used (Figure 15). Once again, the exception is to be found on the Islands: the quality of life index is the same as in the South ${ }^{\mathrm{ao}}$, but the number of pacts signed is much higher (with values similar to Central Italy).

\section{Conclusions}

Security Pacts are an innovative instrument aimed at governing security that were particularly popular among Italian municipalities, provinces and regions between 2007 and 2009. The analysis reported in this paper has helped us to particularly understand why such pacts acquired specific territorial configurations rather than others, even to the extent of drawing borders different from institutionally established administrative boundaries.

The first hypothesis, which assumed a correlation between the territorial configurations of pacts and the political colour of the contracting authorities and the central government, does not seem to provide a satisfactory explanation for this result. The importance of the political and ideological cleavage, in particular, seems to be contradicted by the following empirical findings: first, pacts were signed by both right-wing and left-wing governments and administrations; second, some pacts were signed by administrations of a particular political affiliation and implemented, without substantial changes, by different administrations; third, some pacts ratified the collaboration between local authorities at different territorial levels that were not (not all and not always) homogeneous in terms of political affiliation.

The second hypothesis, that the population size and demographic density of the affected areas explain the spatial configuration of the instrument seems to explain some, although not all, of the cases related to the pacts signed in areas characterized by low levels of demographic density, and the presence of small and very small-sized municipalities.

In this context, the third explanatory hypothesis gains more strength, taking the social and economic conditions of the territory as the independent variable. The data show that a high level of income and quality of life at the regional and municipal level was connected with a higher interest in signing pacts.

To explain the causal relationships between the level of income and quality of life at the regional and municipal level, and the capacity of the wealthier classes to improve policies based on security, a new hypothesis may be suggested at this stage. The spatial configurations of pacts may suggest that those communities used Security Pacts as pre-emptive rather than reactive instruments, unlike high-density urban communities.

Future research on this variable may therefore verify or falsify the hypothesis that the wealthier classes (although smaller and isolated in the territory as a community) are actually able to organize defensive strategies by leveraging their capacity to organize themselves; starting from the pre-emptive protection of the territory (thus anticipating the possible causes of social disadvantage related to crime), the environment, the level of economic activity, and the form of living spaces. This ability means that they are able to overcome ideological barriers, both on the leftright axis, and in relation to the traditional administrative boundaries of reference. While it is true that one of the declared objectives of the introduction of Security Pacts in Italy was to encourage the production of the security good in terms of quality of life, we hereby claim that most of the administrations involved were those in areas that already enjoyed the highest levels of quality of life. In conclusion then, we may assume, for future agenda, that pacts were mostly used to defend the status quo (and promote the already safe areas), rather than to fill an existing security gap or helping others to cope with security-related issues.

\section{Endnotes}

${ }^{a}$ Author translation.

${ }^{\text {b }}$ Contracts can be "vertical" if they involve different levels of government on a different geographic scale, "horizontal" when they involve different local institutions, or "functional" if they belong to the same level of governance. In several empirical studies the simultaneous presence of both dimensions was detected (Bobbio 2006: 70, author translation).

${ }^{c}$ The first aspect (the nature of the agreements) is functional to allow a distinction to be made between the research topic and the traditional negotiation policies. The second (matters of public interest such as the content of the contract) is necessary to make a distinction between a public contract and a private contract (Bobbio 2000: 113, author translation).

${ }^{\mathrm{d}}$ For more details, see Le Galés (1997: 444), Fiasco (2001: 26-27), Procaccini (2003: 410), Braccesi (2005: 30), Giovannetti (2009: 131), Antonelli (2010: 87-88), Calaresu (2013: 61-62).

${ }^{\mathrm{e}}$ On the basis of Article 439, Paragraph 1 of Italian Law No. 296/2006 (2007 Financial Act), Prefects are authorized to enter into agreements with the regions and the local authorities for the implementation of special programmes.

${ }^{\mathrm{f}}$ Bari, Bologna, Cagliari, Catania, Florence, Genoa, Milan, Naples, Palermo, Rome, Turin.

${ }^{\mathrm{g}}$ The division is based on the Nomenclature of Territorial Units for Italian Statistics (NUTS:IT) used for statistical purposes at the European Union (Eurostat 2008). The NUTS country codes suggest a subdivision into three levels: 1) Breakdown by Geographical Areas; 2) Breakdown by regions; 3) Division based on provincial borders. 
${ }^{\mathrm{h}}$ Agreements signed between $18^{\text {th }}$ of May 2007 (the date of the first Security Pact) and $31^{\text {st }}$ of December 2009 (the end of the period under study).

${ }^{\mathrm{i}}$ For further investigation on this matter see Calaresu (2013).

${ }^{j}$ The Program for Computer-Assisted Coding of Events, available at www.pc-ace.com, organizes information in a relational data format, with different text elements stored in different computer tables in the same database. PCACE does not do the hard work of automatically parsing text within the categories of a story grammar (Artificial Intelligence has yet to deliver on early promises of computer understanding of natural languages). All PC-ACE does (or any other currently available software of textual analysis, for that matter, except for basic word counts) is to provide a computerized tool that makes the task of sorting information within the categories of a "story grammar" easier and more reliable for a human coder.

${ }^{\mathrm{k}}$ For further information about the empirical results obtained with the SQL interrogation of the 07_SecuPacts_09 database (with particular reference to the analysis of qualitative data via network models and social network analysis), see Calaresu (2012, 2013).

${ }^{1}$ ArcGIS software is a system that allows the acquisition, recording, analysis, and visualization of spatial data and information derived from geographic data (geo-referenced data).

${ }^{\mathrm{m}}$ IBM SPSS Statistics Software 21, 64 bit. Microsoft Licensed version.

${ }^{\mathrm{n}}$ For a better understanding of the significance of the project, on the basis of the performed "semantic triples", see Franzosi (2010): 139-140.

${ }^{\circ}$ Part from the city of Palermo that postponed the signing of a pact, since local elections were being held at that time, all metropolitan areas that signed pacts with the Ministry of Home Affairs complied with their commitment to adopt their own security pact within the limit of 60 days from the signing of the National Pact.

${ }^{\mathrm{P}}$ The label other refers to an event including administrators not belonging to the main political parties, based on data extracted from the Ministerial Registry. This means not belonging to any of the following categories: centro-destra, centro-sinistra, centro-destra and centrosinistra with contrassegni ufficiali; liste civiche. In detail (as reported by the Registry and in alphabetical order) the parties were:

- Alleanza Popolare (ALL. POP.);

- Centro;

- Contadini Monarchici (CM);

- Lista civica (various);

- Lista Civica Indipendente;

- Unione Democratici Cristiani (UDC);
- Unione Democratici Cristiani - others;

- Uniti per Cambiare;

- Lega Nord (LN);

- Lega Nord - others.

- Margherita (DL).

The other category also includes the cases not uploaded on the Ministerial database (reported by the Registry as: unspecified) and the cases reporting missing and unavailable information (see Associazione Openpolis 2014). And also, the municipalities managed by external commissioners (reported as: Commissario Prefettizio) at the time of the signing of a pact.

${ }^{\mathrm{q}}$ This is the only piece of information made available by the Registry of Local and Regional Directors. Please note that, since the time of the signing of a pact, the political orientation of the local administration might have changed.

${ }^{\mathrm{r}}$ Capiago Intimiano, Carimate, Cermenate, Cucciago, Figino Serenza, Novedrate.

${ }^{\text {s} A l z a n o ~ d e l ~ P a r c o, ~ A l z a t e ~ B r i a n z a, ~ A p p i a n o ~ G e n t i l e, ~}$ Arosio, Bregnano, Brenna, Bulgarograsso, Cabiate, Cadorago, Carbonate, Cantù, Capiago Intimiano, Carimate, Carugo, Cermenate, Cirimido, Cucciago, Fenegrò, Figino Serenza, Guanzate, Inverigo, Limido Comasco, Locate Varesino, Lomazzo, Lurago d'Erba, Lurago Marinone, Mariano Comense, Monguzzo, Mozzate, Novedrate, Oltrona San Mamette, Rovellasca, Rovello Porro, Turate, Veniano, Vertemate con Minoprio.

${ }^{\mathrm{t} A}$ Albiolo, Beregazzo, Binago, Bizzarone, Cagno, Castelnuovo Bozzente, Cavallasca, Drezzo, Faloppio, Gironico, Lurate Caccivio, Olgiate Comasco, Parè, Rodero, Ronago, Solbiate, Uggiate Trevano, Valmorea.

uBarni, Bellagio, Carlazzo, Blevio, Brunate, Caglio, Civenna, Faggeto Lario, Lasnigo, Lezzeno, Magreglio, Nesso, Pognana Lario, Rozzago, Sormano, Torno, Valbrona, Veleso, Zelbio.

'Bene Lario, Cavargna, Corrido, Cusino, Grandola e Uniti, Menaggio, Plesio, Porlezza, San Bartolomeo Val Cavargna, San Nazzaro Val Cavargna, San Siro, Valrezzo, Valsolda.

${ }^{\mathrm{w}}$ Arco, Bardolino, Brenzone, Castelnuovo del Garda, Desenzano, Garda, Gardone Riviera, Gargnano, Lazise, Limone del Garda, Lonato del Garda, Malcesine, Manerba del Garda, Molina di Ledro, Moniga del Garda, Nago Torbole, Padenghe sul Garda, Peschiera del Garda, Riva del Garda, Salò, San Felice del Benaco, Sirmione, Tignale, Torri del Benaco, Toscolano Maderno, Tremosine.

${ }^{x}$ Capraia e Limite, Castelfiorentino, Cerreto Guidi, Certaldo, Empoli, Fucecchio, Gambassi Terme, Montatone, Montelupo Fiorentino, Montespertoli, Vinci.

${ }^{y_{B}}$ Bagno a Ripoli, Calenzano, Campi Bisenzio, Fiesole, Impruneta, Lastra a Signa, Pontassieve, Scandicci, Sesto Fiorentino, Signa. 
${ }^{\mathrm{z}}$ Author translation.

${ }^{\text {aa }}$ Likely to be connected to the incidence of predatory crime rates or migratory waves in hot suburbs, or neighbourhoods characterized by urban and/or social decay, as well as issues related to urban redevelopment.

${ }^{\mathrm{ab}}$ On this matter, see Antonietta Mazzette: "[...] [Territorial] governmental policies should be based on an overall idea of what happens in a certain area, rather than individual local limited skills. But this means overcoming strict administrative boundaries and rethinking the territory as a composite urban system" (Mazzette 2003b: 24, author translation).

${ }^{\mathrm{ac}}$ The issues related to institutional representation, moreover, are a long-time concern for the Italian cities, regardless of their demographic density and their extension. The issue connected to borders, for instance, is closely related to the allocation of competences and institutional responsibility. Also for this reason, many regard the institutional traditional boundaries as not being adequate any more, and so is the allocation of competencies among the actors: "[...] the administrative boundaries still taken into account, have [therefore] become an obstacle and hinder the most important dynamics taking place on the territory" (Mazzette 2003b: 24, author translation).

${ }^{\text {ad }}$ Author translation.

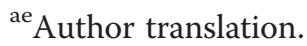

${ }^{\text {af }}$ Author translation.

${ }^{\mathrm{ag}}$ Useful to represent the geographical distribution of wealth.

${ }^{\mathrm{ah}}$ As a definition of the Gross Domestic Product: "GDP, and thus GDP per inhabitant, provides a measure of the total economic activity in a region. It may be used to compare the degree of economic development of regions. GDP does not measure the income ultimately available to private households in a region" (Eurostat, 2008: 2, footnote 1).

${ }^{\mathrm{ai}}$ The PPS (purchasing power standard) is an artificial currency that takes into account differences in national price levels. This unit allows meaningful volume comparisons of economic indicators over countries" (Eurostat, 2008: 2 , footnote 2).

${ }^{\text {aj }}$ As reported in Eurostat (2008: 2, footnote 3): “These data are based on the Nomenclature of Territorial Units for Statistics (NUTS) as last modified in February 2007. NUTS 2006 provides a uniform, consistent breakdown of territorial units for the production of regional statistics for the EU. Level 2 of the nomenclature has 271 regions: Belgium (11), Bulgaria (6), the Czech Republic (8), Denmark (5), Germany (39), Ireland (2), Greece (13), Spain (19), France (26), Italy (21), Hungary (7), the Netherlands (12), Austria (9), Poland (16), Portugal (7), Romania (8), Slovenia (2), Slovakia (4), Finland (5), Sweden (8) and the United Kingdom (37). Estonia, Cyprus, Latvia, Lithuania, Luxembourg and Malta are all considered as single regions at NUTS 2 level. For a list of the European statistical regions see: http://epp.eurostat.ec.europa.eu/portal/page/ portal/nuts_nomenclature/introduction".

${ }^{\mathrm{ak}}$ The vertical and horizontal line in the figure corresponds to the average values (see Figure 14).

al"In 2007, the GDP per inhabitant in Purchasing Power Standards (PPS) terms, in EU 27, ranged between $26 \%$ of the EU-27 average in the region of Severozapaden (Bulgaria), and 334\% of the average of Inner London (UK)" (Eurostat 2008: 1).

${ }^{a m}$ This particular measure seems to be the most suitable to understand the quality of life and the levels of economic development in a specific area, compared with the GDP value that focuses too much on the economic wealth produced.

${ }^{\mathrm{an}}$ The vertical and horizontal line in the figure corresponds to the average values (see Figure 15).

${ }^{\mathrm{a}}$ This is due to the fact that Italia Oggi (2007) does not make any distinction between the South and the Islands, including both in the same category.

\section{Competing interests}

The authors declare that they have no competing interest.

\section{Authors' contributions}

This article is the result of joint research undertaken by the two authors. MC conceived of the study, carried out the collection of data using Quantitative Narrative Analysis (QNA) and the Program for Computer-Assisted Coding of Events (PC-ACE), performed the statistical analysis, implemented the spatial maps using ArcGIS software, provided the interpretation of empirical data and drafted the manuscript. MT participated in the design of the study, prepared the hypothetical framework of the analysis, and edited the manuscript. Both authors read and approved the final manuscript.

\section{Acknowledgements}

The authors wish to thank the contribution of Claudius Wagemann at Goethe Universität for reading and evaluating a very first draft of this work at Istituto Italiano di Scienze Umane - Scuola Normale Superiore, Florence-Pisa. This manuscript acknowledges the technical support with ArcGIS software of Gianluca Melis at University of Sassari, and the effort in the acquisition, verification and interpretation of empirical and statistical data of Stefania Vicari at University of Leicester. Tribute must be paid also to Roberto Franzosi at Emory University for his advice related to the use of Quantitative Narrative Analysis (QNA) and for helping us to prepare a coding scheme for codifying non-narrative text sections of "Security Pacts" with the Program for Computer-Assisted Coding of Events (PC-ACE). Additionally, our acknowledgments go to Harvey Molotch and Ann Morning at New York University, Giovanni Maciocco at University of Sassari and Rossella Selmini at University of Minnesota for discussing and debating ideas, concepts and methods related to this work from a wider disciplinary perspective. Finally, a special thanks to Sara Aime and Tonito Solinas at University of Sassari, for their continued support in proof-reading and editing this work.

\section{Funding}

The research has been partially founded by a PRIN National Grant 2010-2011 (Ministry of Education, University and Research) entitled "Crisi economiche e qualità delle democrazie in Europa - Economic crisis and the quality of democracies in Europe". Scientific National Coordinator: Leonardo Morlino. Leading Institution: Libera Università Internazionale degli Studi Sociali Guido Carli (LUISS), Rome, Italy. Scientific Local Coordinator: Mauro Tebaldi. Local Institution: University of Sassari, Department of Political Sciences, Communication Sciences and Information Engineering, Sassari, Italy. Duration: 36 months. Protocol number: 2010WKTTJP_007. Area: 14 
Received: 29 August 2014 Accepted: 2 December 2014

Published online: 09 January 2015

\section{References}

Allulli M (2010) Le politiche urbane in Italia tra adattamento e frammentazione. CITTALIA - Fondazione ANCI Ricerche, Roma

Allulli M, Tortorella W (2014) Città metropolitane. La lunga attesa. Marsilio, Venezia

Amendola G (2003) Paure in città. Strategie ed illusioni delle politiche per la sicurezza urbana. Liguori Editore, Napoli

Antonelli V (2010) L'esperienza dei "Patti per la sicurezza" nel biennio 2007-2008. In: Pajno A (ed) La sicurezza urbana. Maggioli, Sant'Arcangelo di Romagna

Associazione Openpolis (2014) Progetto: Open Municipio. In: http://www. openpolis.it/progetti/openmunicipio/

Baratta A (2001) El Concepto Actual de Seguridad en Europa. Revista Catalana de Seguridad Publica 8:17-30

Battistelli F, Lucianetti L (2010) La sicurezza urbana tra politcs e policy. In: Pajno A (ed) La sicurezza urbana. Maggioli Editore, Sant'Arcangelo di Romagna

Bauman Z (2005) Trust and Fears in the Cities. Polity Press, Cambridge

Bauman Z (2008) Liquid Fear. Polity Press, Cambridge

Bobbio L (2000) Produzione di politiche a mezzo di contratti nella pubblica amministrazione italiana. Stato e Mercato 58:111-142

Bobbio L (2006) Le politiche contrattualizzate. In: Donolo C (ed) II futuro delle politiche pubbliche. Mondadori, Milano

Boutellier H (2004) The Safety Utopia: Contemporary Discontent and Desire as to Crime and Punishment. Kluwer Academic Publishers, Dordrecht-Boston

Braccesi C (2005) Le politiche di sicurezza urbana in Italia. In: Braccesi C, Selmini R (eds) Sicurezza urbana e ruolo della polizia locale. Maggioli Editore, Sant'Arcangelo di Romagna

Braccesi C, Selmini R (2005) Sicurezza urbana e ruolo della polizia locale. Maggioli Editore, Sant'Arcangelo di Romagna

Calaresu M (2012) La politica di sicurezza urbana. L'esperienza dei "patti per la sicurezza" nel triennio 2007-2009. Rivista Italiana di Politiche Pubbliche 3:387-418

Calaresu M (2013) La politica di sicurezza urbana. II caso italiano (1994-2009). Franco Angeli, Milano

Calaresu M, Padovano S (2011) Gli strumenti top-down nel governo della sicurezza: l'esperienza pattizia e delle ordinanze sindacali nel triennio 2007-2009. In: Padovano S. La Questione Sicurezza. Genesi e sviluppo di un concetto equivoco. Rubettino, Soveria Mannelli

Castels R (2003) L'insécurité Sociale: Qu'est-ce Qu'être Protégé? Éd. du Seuil, Paris

Chiodini L, La Nave M (2010) Atlante dei piccoli comuni. CITTALIA - Fondazione ANCl Ricerche, Roma

Curbet J (2008) El Rey Va Desnudo! Inseguridad. Justicia y Policia, Editorial UOC, Barcelona

De Micheli C, Tebaldi M (2013) Sicurezza individuale e ordine pubblico. In: Morlino L, Piana D, Raniolo F (eds) La qualità della democrazia in Italia. II Mulino, Bologna

Dei Delitti e Delle Pene (2002) Numero monografico. Governare la sicurezza. Attori, politiche e istituzioni in Europa 1-2-3:177-190

Eurostat (2008) Regional GDP per Inhabitant in 2007. Eurostat News Release, Bruxelles

Fiasco M (2001) La sicurezza urbana. Modelli di prevenzione e gestione. Protocolli e contratti -Servizi dell'ente locale e delle Forze di Polizia. II Sole 24 Ore, Milano

Franzosi R (2004) From Words to Numbers: Narrative, Data, and Social Science. Cambridge University Press, Cambridge

Franzosi R (2010) Quantitative Narrative Analysis. Sage, Thousand Oaks, CA

Garland D (1996) The Limits of the Sovereign State. The British Journal of Criminology 36(4):445-465

Garland D (2001) The Culture of Control: Crime and Social Order in Contemporary Society. Oxford University Press, Oxford

Gaudin JP (ed) (1996) La Négociation des Politiques Contractuelles. L'Harmattan, Paris

Gaudin JP (1999) Gouverner par Contrat. L'action Publique en Question. Presses de SciencesPo, Paris

Giovannetti M (2009) Le politiche europee in materia di sicurezza urbana e prevenzione della criminalità. In: CITTALIA - Fondazione ANCI Ricerche (ed) Oltre le ordinanze: I sindaci e la sicurezza urbana. CITTALIA- Fondazione ANCI Ricerche, Roma
Governo Italiano - Ministero dell'Interno (2007) Patto per la sicurezza delle città metropolitane con ANCl. http://www.interno.gov.it/mininterno/export/sites/ default/it/sezioni/sala_stampa/notizie/sicurezza/2007_03_20_Patto_per_la_ sicurezza_tra_il_Ministero_dellxInterno_e_IxAnci.html

Governo Italiano - Ministero dell'Interno (2008) Patto per la Sicurezza dei piccoli comuni con ANPCI. http://www.interno.gov.it/mininterno/export/sites/ default/it/assets/files/15/0342_patti_sicurezza_piccoli_comuni.pdf

Hughes G, Edwards A (eds) (2002) Crime Control and Community: the New Politics of Public Safety. Willan Publishing, Devon

Hughes G, McLaughlin E, Muncie J (eds) (2002) Crime Prevention and Community Safety: Future Directions. Sage, London

Inglehart R (1996) Modernization and Postmodernization. Cultural Economic and Political Change in 43 Societies. Princeton University Press, Princeton

Italia Oggi (2007) Rapporto sulla qualità della vita nei comuni italiani. Roma

Lagrange H (1993) La Peur a la Recherche du Crime. Déviance et Société 17 (4):385-417

Lascoumes P, Le Galés P (eds) (2004) Gouverner par les Instruments. Presses de Sciences Po, Paris

Le Galés P (1997) Relazioni centro-periferia e politiche pubbliche in Francia. Flessibilità e complessità senza federalismo. In: Dente B (ed) Governare con il federalismo. Fondazione Agnelli, Torino

Maciocco G (2007) Architecture Environment and Beyond. Skira editore, Milano

Martin L, Selmini R (2000) I progetti per la sicurezza nelle città italiane. Quaderni di Città Sicure 6(20B):27-36

Mazzette A (ed) (2003a) La vulnerabilità urbana. Segni, forme, e soggetti dell'insicurezza nella Sardegna settentrionale. Liquori Editore, Napoli

Mazzette A (2003b) Perché la città è "vulnerabile". In: Mazzette A (ed) La vulnerabilità urbana. Segni, forme, e soggetti dell'insicurezza nella Sardegna settentrionale. Liguori Editore, Napoli

Morlino L, Piana D, Raniolo F (eds) (2013) La qualità della democrazia in Italia. II Mulino, Bologna

Moroni S, Chiodelli F (2014) Municipal regulations and the use of public space: local ordinances in Italy. City, Territory and Architecture 1:11, doi:10.1186/ 2195-2701-1-11

Pavarini M (2006a) L'amministrazione locale della paura. Ricerche tematiche sulle politiche di sicurezza urbana in Italia. Carocci, Roma

Pavarini M (2006b) L'aria delle città rende (ancora) liberi? Dieci anni di politiche locali di sicurezza. In: Pavarini M (ed) L'amministrazione locale della paura. Ricerche tematiche sulle politiche di sicurezza urbana in Italia. Carocci, Roma

Pajno A (ed) (2010) La sicurezza urbana. Sant'Arcangelo di Romagna, Maggioli Editore

Procaccini G (2003) I sistemi di qualità e le Forze di polizia. Instrumenta 20:400-435

Recasens i Brunet A (2007) La Seguridad y sus Politicas. Atelier, Barcelona

Rimmon-Kenan S (1983) Narrative Fiction: Contemporary Poetic. Methuen, London

Selmini R (ed) (2004) La sicurezza urbana. II Mulino, Bologna

Selmini R (2005a) Le politiche di sicurezza urbana in Europa. In: Braccesi C, Selmini R (eds) Sicurezza urbana e ruolo della polizia locale. Maggioli Editore, Sant'Arcangelo di Romagna

Selmini R (2005b) Towards Città Sicure? Political Action and Institutional Conflict in Contemporary Preventive and Safety Policies in Italy. Theoretical Criminology 9(3):307-323

Simon J (2007) Governing through crime. How the war on crime transformed American democracy and created a culture of fear. Oxford University Press, New York

\section{Submit your manuscript to a SpringerOpen ${ }^{\odot}$ journal and benefit from:}

- Convenient online submission

$\checkmark$ Rigorous peer review

- Immediate publication on acceptance

- Open access: articles freely available online

- High visibility within the field

- Retaining the copyright to your article

Submit your next manuscript at springeropen.com 